High Time:

\title{
Cuban TV Serials Spur Debate on Sensitive Social Issues
}

\section{Dixie E. Trinquete MS}

A young doctor with an HIV-positive lover; a teen victim of sexual violence; a battered wife; a man who has recently discovered his homosexuality and is suffering the stigma of a machista society... these are just some of the characters who have populated primetime Cuban TV serials over the last few years. These shows are seen by millions across the country, a cultural phenomenon unrivalled in audience share only during baseball season. While these newer telenovelas are just as fictional as their predecessors, they have outgrown the term "soap operas" and merit greater attention: the lives in their storylines hit close to home and have given their audience cause for reflection.

In fact, surfing Cuban TV channels today, you might conclude that finally television has responded to oft-repeated demands to treat real-life situations, instead of hosting the "light and tearful" dramas common in Latin American television. Nighttime TV has practically left behind serials depicting centuries past, except for the occasional Brazilian soap opera. Animated public service announcements advocate respect for sexual diversity. Other programs-such as Conexión and Quédate conmigo, aimed at young adults, or Diálogo abierto and El triángulo de la confianzaaddress sexually transmitted infections, alcohol and drug abuse, and domestic and gender-based violence.

This shift has unleashed passionate debates nationwide. Not unexpectedly, those in public health and the social sciences applaud the change. But not everyone is smiling at their TV set. Calls from angry viewers, public protests and more than a few offensive letters to shows' directors all confirm what studies of human behavior have already proven: attitudes tend to take longer to change than public policy.

Still other viewers have questioned whether TV serials are the place to portray such socially-complex themes. However, it is clear that public debate in the mass media is indispensable for a society to look itself in the mirror, all the more so if themes concern critical social problems or serious threats to the public's health such as HIVIAIDS or drugs. The first step in confronting issues such as gender-based violence or respect for sexual diversity, therefore, is to make them visible. Credit is due then to Cuban television for breaking the "illegitimate silence" that lasted for too many years.

The resulting national polemic_-fast, often furious and infuriating-is a good thing, as the shakeup is leading to movement in people's minds and actions. The TV series La cara oculta de la luna, popularly known as the "AIDS telenovela," was a gamechanger in this sense. It wove together the stories of five HIVpositive characters, and achieved enviable results.

Not only did the serial break audience viewer records, but it also positively influenced health-promoting behavior in the general public: 22,000 more Cubans than usual spontaneously requested HIV tests in the trimester following the first season. And the National STI-HIVIAIDS Prevention Center registered an unprecedented 4256 calls on its HIVIAIDS hotline and 750 emails requesting advice. What's more, La cara oculta... opened the door to wider serious debate on issues implied but not treated in the series itself.

The first step in confronting
issues such as gender-based
violence or respect for sexual
diversity is to make them
visible. Credit is due to Cuban
television for breaking the
"illegitimate silence" that
lasted for too many years.

Later shows such as Historias del fuego, Oh La Habana and Aquí estamos have shaken off melodrama and inserted themselves fully into a process of social transformation-although with an occasional tendency to lecture or point fingers at their viewers. Thus, I agree with the assessment from a producer who for many years was at the helm of Cuban television's fiction division: shows that audaciously treat difficult social themes are worth the risk, "even if we make mistakes," precisely because they challenge audiences to wake up, to debate and rethink their opinions.

In short, Cuban television has embarked on a trial-and-error process that nevertheless opens minds and moves thinking forward. One example of qualitative change is apparent from the response to the latest series, Bajo el mismo sol, which also treats issues such as gay and bisexual relations. While some viewers have criticized its episodes as "too crude," the very essence of their critique has shifted the debate from whether these themes should be seen at all on screen to how they should be portrayed.

The first step is the longest according to the Chinese proverb. That step has been taken.

And television's significant influence has contributed immeasurably to a national social agenda that includes culturally sensitive gender-related and health issues. But it is an agenda that is becoming broader and more complex: in this context, TV directors will have to be bold enough to take on fresh challenges and risks to meet new audience demands and intelligently advance public debate. -1 -

Submitted: March 20, 2012

Approved for publication: March 24, 2012

Disclosures: None 